\title{
Review \\ Solution combustion derived nanocrystalline macroporous wollastonite ceramics
}

\author{
R.P. Sreekanth Chakradhar ${ }^{a}$, B.M. Nagabhushana ${ }^{b}$, \\ G.T. Chandrappa ${ }^{\text {b,* }}$, K.P. Ramesh ${ }^{\text {a }}$, J.L. Rao ${ }^{\mathrm{c}}$ \\ a Department of Physics, Indian Institute of Science, Bangalore 560012, India \\ b Department of Chemistry, Bangalore University, Bangalore 560001, India \\ ${ }^{c}$ Department of Physics, S.V. University, Tirupati 517502, India
}

\begin{abstract}
Macroporous nanocrystalline wollastonite $\left(\mathrm{CaSiO}_{3}\right)$ ceramic powders have been prepared by a simple, low-temperature initiated, selfpropagating and gas producing solution combustion process. The effects of temperature on crystalline phase formation, amount of porogens and particle size of porous $\mathrm{CaSiO}_{3}$ and its structure have been investigated. It is observed that heat-treated wollastonite at 950 and $1200{ }^{\circ} \mathrm{C}$ shows single phase of $\beta-\mathrm{CaSiO}_{3}$ and $\alpha-\mathrm{CaSiO}_{3}$, respectively. The results show that the phase transformation temperatures of the solution combustion derived wollastonite powder were found to be lower compare to the powders obtained via solid-state reaction method. It was observed that the average particle size of the annealed $\mathrm{CaSiO}_{3}$ samples is in the range $29-50 \mathrm{~nm}$. The density of the as formed powder is $1.73 \mathrm{~g} \mathrm{~cm}^{-3}$ where as the bulk density is $2.321 \mathrm{~g} \mathrm{~cm}^{-3}$, which corresponds nearly to $80 \%$ of the theoretical density $\left(2.91 \mathrm{~g} \mathrm{~cm}^{-3}\right)$. The samples calcined for $3 \mathrm{~h}$ at $950{ }^{\circ} \mathrm{C}$ have $51.1 \%$ of theoretical density with a porosity of $17.5 \%$, however, the porosity increases with calcination and at $1200{ }^{\circ} \mathrm{C}$ has a large porosity of $31.6 \%$. The microstructure and morphology were studied by scanning electron microscope (SEM) and it is interesting to note that with increase in calcination temperature, the samples become more porous and the pore diameter increases from 0.25 to $8 \mu \mathrm{m}$. The surface area of the as formed, 950 and $1200{ }^{\circ} \mathrm{C}$ calcined samples were $31.93,0.585$ and $3.48 \mathrm{~m}^{2} \mathrm{~g}^{-1}$, respectively. The structure of $\mathrm{CaSiO}_{3}$ has been investigated by ${ }^{29} \mathrm{Si}$ MAS NMR. The shape of the $Q_{n}$ distribution has been examined for the as formed $\mathrm{CaSiO}{ }_{3}$ as well as calcined $\left(950^{\circ} \mathrm{C}\right)$ sample.
\end{abstract}

Keywords: Powders chemical preparation; Macroporous; Nanocrystalline; Ceramics; Biomedical applications

\section{Contents}

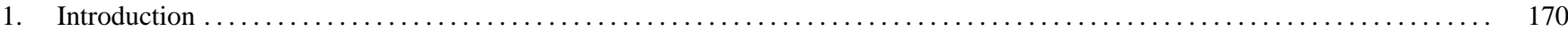

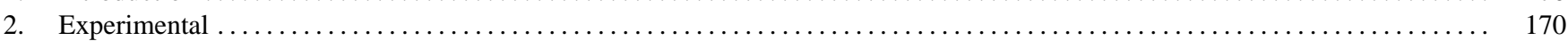

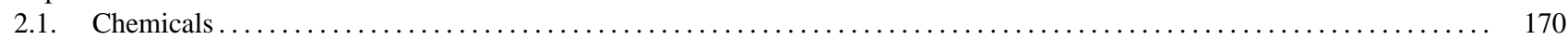

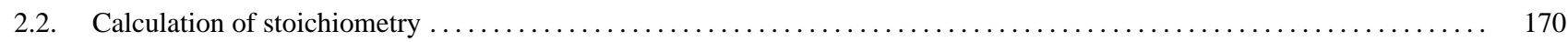

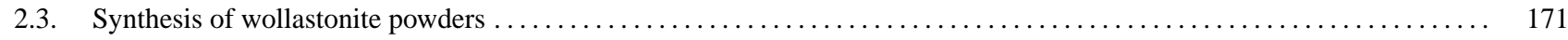

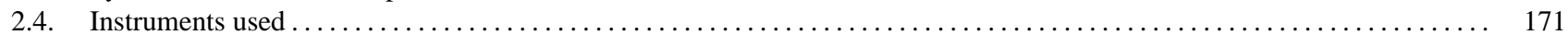

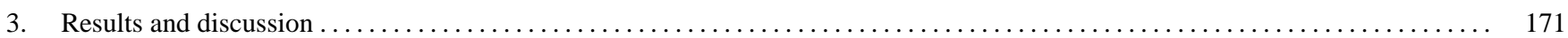

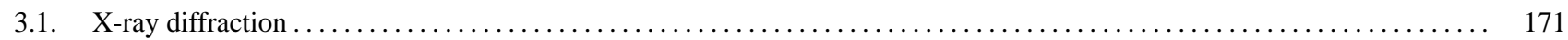

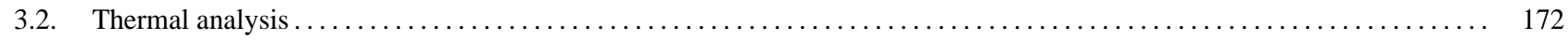

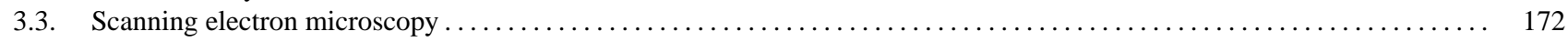

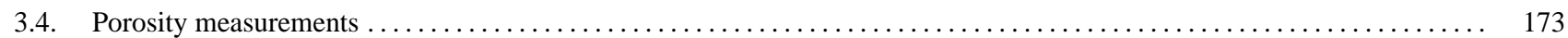

* Corresponding author. Tel.: +91 8023523154; fax: +91 8023523154 .

E-mailaddresses: chakra72@physics.iisc.ernet.in (R.P. Sreekanth Chakradhar), gtchandrappa@yahoo.co.in (G.T. Chandrappa). 


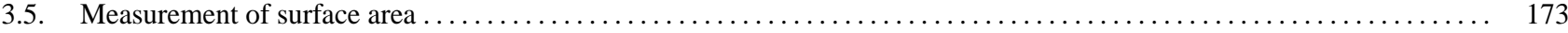

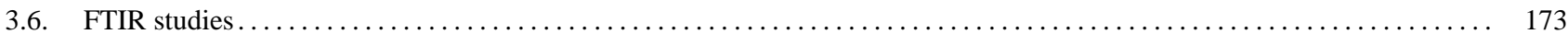

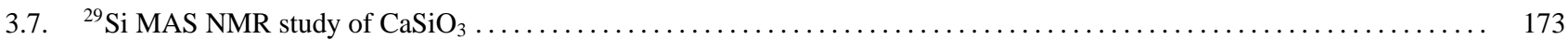

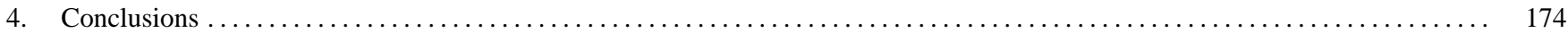

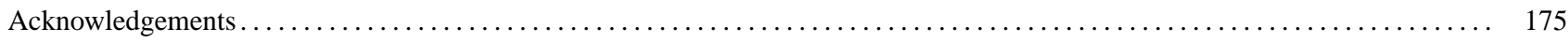

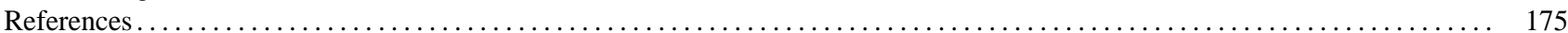

\section{Introduction}

In recent years, materials with porous architecture and high surface area are being developed for numerous potential applications in nanotechnology. Particular areas of interest include catalysis and separation science [1-6], molecular sieves, zeolites, hybrid optics, bio ceramics and many more. The need for such materials is essentially because of the technological progress. The development and use of such promising materials is also an important factor in solving economic problems, which include the shortage of natural resources. Since the discovery of the ordered mesoporous silica [1], a lot of porous materials have been synthesized using surfactants as template. However, most of these materials are unstable on removal of the surfactant and the porous skeleton collapse easily when heated above $400^{\circ} \mathrm{C}$ [5,7-13]. It is believed that the collapse of mesostructure in mesoporous materials might be related to the structural rearrangement due to crystallization after removal of organic templates during calcination. Therefore, new methods of synthesis are highly desirable. In addition, the thermo stability, i.e. the ability of maintaining porous structure at high temperatures is a key to both fabrication of ordered porous material and its practical applications. High thermal stability of porous materials can combine porous structure with traditional ceramic science and technology, leading to wide applications.

As a part of our programme to study porous materials [14], we have attempted to synthesize a porous composite ceramic material wollastonite $\left(\mathrm{CaSiO}_{3}\right)$ by a novel low-temperature initiated, self-propagating and gas producing solution combustion process. Wollastonite is a mineral that has many uses in numerous branches of national economies over the world. The growing demands for wollastonite in recent years are evidenced by the steady increase in its production worldwide [15].

Silicates of calcium have a combination of properties, such as good and high temperature strength, creep resistance, chemical inertness, thermal stability, low thermal expansion and low thermal conductivity, hence are used in technological applications [16,17]. $\mathrm{Pb}$ and $\mathrm{Mn}$ activated wollastonite act as yellow range lamp phosphor material. The wollastonite containing materials are used for the production of special radio ceramics, sanitary components, porcelain materials, lining bricks, glaze and flux [18]. Wollastonite $\left(\mathrm{CaSiO}_{3}\right)$ ceramics are also used as a biomaterial in medical industry for artificial bone and dental root because it showed good bioactivity and biocompatibility [19-23].

The addition of wollastonite to ceramic mixtures makes it possible to shorten the firing time, to decrease the firing temperature, to reduce shrinkage and to impart strength to materials. [24,25]. This possibility of obtaining stronger materials based on wollastonite opens new application areas. The high strength and porosity, low thermal conductivity and non-wettability in aluminum alloys makes ceramic materials based on natural wollastonite resistant to such alloys, which is very significant in the production of heat insulating ceramics for lining of casting equipment and checkers in metallurgy and the automobile industry.

In spite of such a wide range of applications as on today, the data on wollastonite and related production technologies are a very few [26]. In view of its practical importance, we have extended the studies on synthesis and characterization of wollastonite.

\section{Experimental}

\subsection{Chemicals}

The starting materials used for preparation of $\mathrm{CaSiO}_{3}$ in the present study were of Analar grade calcium nitrate $\mathrm{Ca}\left(\mathrm{NO}_{3}\right)_{2} \cdot 4 \mathrm{H}_{2} \mathrm{O}$, fumed silica $\left(\mathrm{SiO}_{2} 99.9 \%\right.$, surface area $\left.200 \mathrm{~m}^{2} \mathrm{~g}^{-1}\right)$ were the source of $\mathrm{Ca}$ and $\mathrm{Si}$. The fuel diformyl hydrazine $\left(\mathrm{C}_{2} \mathrm{H}_{4} \mathrm{~N}_{2} \mathrm{O}_{2}, \mathrm{DFH}\right)$, used for combustion synthesis, was prepared in our laboratory by the reaction of formic acid and hydrazine hydrate as described in the literature [27].

\subsection{Calculation of stoichiometry}

The stoichiometry of the redox mixture used for combustion process was calculated using the total oxidizing and reducing valencies of the ingredients which serve as numerical coefficients for the stoichiometric balance so that the equivalence ratio $\left(\phi_{\mathrm{e}}\right)$ is unity and the energy released by the combustion is maximum [28]. According to the concept used in propellant chemistry the valence of $\mathrm{C}=+4, \mathrm{H}=+1$, divalent metal ions $=+2$, trivalent metal ions $=+3$ and so on and $\mathrm{O}=-2$. The valence of nitrogen is considered to be zero. Based on these considerations, calcium nitrate has an oxidizing valence of -10 and DFH a reducing valence of +8 . The total valence of $\mathrm{SiO}_{2}$ is zero. 
For the preparation of wollastonite, the required mole ratio of $\mathrm{Ca}\left(\mathrm{NO}_{3}\right)_{2} \cdot 4 \mathrm{H}_{2} \mathrm{O}: \mathrm{SiO}_{2}: \mathrm{DFH}$ becomes 1:1:1.25.

\subsection{Synthesis of wollastonite powders}

Calcium nitrate and DFH were dissolved in a minimum quantity of water in a cylindrical petri dish of $300 \mathrm{ml}$ capacity, to this fumed silica was added and dispersed well using magnetic stirrer for half an hour. The heterogeneous redox mixture was rapidly heated in a muffle furnace maintained at $500 \pm 10^{\circ} \mathrm{C}$. DFH is a good fuel like other $\mathrm{N}-\mathrm{N}$ bonded hydrazine derivatives, e.g. carbohydrazide $(\mathrm{CH})$, tetraformal trisazine (TFTA), oxalyl dihydrazide $(\mathrm{ODH})$ and maleic hydrazide $(\mathrm{MH})$ which are known [29] to decompose to give $\mathrm{NH}_{3}, \mathrm{~N}_{2}, \mathrm{CO}_{2}$ and $\mathrm{HNCO}$. These gaseous products along with oxides of nitrogen formed by the thermal decomposition of metal nitrates are hypergolic at $350-500^{\circ} \mathrm{C}$. The redox mixture when heated at $500{ }^{\circ} \mathrm{C}$ boils froaths and thermally dehydrates forming a honey like gel, which ignites to yield voluminous $\mathrm{CaSiO}_{3}$ powder.

Theoretical equation assuming complete combustion of the redox mixture used for the synthesis of wollastonite may be written as

$$
\begin{aligned}
& 4 \mathrm{Ca}\left(\mathrm{NO}_{3}\right)_{2}+4 \mathrm{SiO}_{2}+5 \mathrm{C}_{2} \mathrm{H}_{4} \mathrm{~N}_{2} \mathrm{O}_{2} \\
& \quad \rightarrow 4 \mathrm{CaSiO}_{3}(\mathrm{~s})+9 \mathrm{~N}_{2}(\mathrm{~g})+10 \mathrm{H}_{2} \mathrm{O}(\mathrm{g})+10 \mathrm{CO}_{2}(\mathrm{~g}) \\
& \quad \sim 7 \text { mol gases } / \mathrm{CaSiO}_{3}
\end{aligned}
$$

The nominal composition of the combustion derived wollastonite samples were also confirmed by EDS.

\subsection{Instruments used}

An X-ray powder diffractometer (Philips PW 1050/70) using $\mathrm{Cu} \mathrm{K} \alpha$ radiation with a Ni filter was used to estimate the crystallinity of the phases. In addition to this thermal analysis (TG-DTA) was also performed using NETZ SCH Simultaneous Thermal Analyzer. The surface morphology, size distribution of the grains and energy dispersive spectroscopy (EDS) of the sample was examined on a JEOL (JSM-840A) scanning electron microscope (SEM). The FTIR spectral studies have been performed on a Perkin-Elmer spectrometer (spectrum 1000) with $\mathrm{KBr}$ pellets. The surface area of the $\mathrm{CaSiO}_{3}$ samples prepared by combustion process was measured by Quanta Chrome Corporation, NOVA 1000 Gas Sorption Analyzer.

${ }^{29}$ Si MAS NMR spectra were recorded on a Bruker DSX 300 spectrometer $\left(B_{0}=7.05 \mathrm{~T}\right)$ operating at a Larmor frequency $59.627 \mathrm{MHz}$ at room temperature. Spinning speeds of $7.2 \mathrm{kHz}$ with an accuracy of better than $20 \mathrm{~Hz}$ were employed. Short single pulses of $5 \mu$ s were applied in order to excite a large spectral range of about $0.2 \mathrm{MHz}$. The repetition delay time was $5 \mathrm{~s}$. The chemical shift was referenced to an external TMS.

\section{Results and discussion}

\subsection{X-ray diffraction}

The phase evaluation of the solution combustion derived as formed and calcined $\left(500,700,950,1100\right.$ and $1200^{\circ} \mathrm{C}$ ) powders of $\mathrm{CaSiO}_{3}$ were examined by powder X-ray diffraction and is shown in Fig. 1. The XRD patterns of as made wollastonite powders exhibit weak crystallinity with $\mathrm{CaO}$ peak at $2 \theta=29.5^{\circ}$. On calcination the $\mathrm{CaO}$ peak disappears and becomes fully crystalline $\beta-\mathrm{CaSiO}_{3}$ at $950{ }^{\circ} \mathrm{C}$. It has also been observed that the peaks of wollastonite become more and more intense with increase in calcination temperatures from 500 to $950{ }^{\circ} \mathrm{C}$. On further increase in calcination temperature from 950 to $1200^{\circ} \mathrm{C}$, the simultaneous existence of $\mathrm{CaSiO}_{3}$ in $\beta$ - and $\alpha$-phases could be observed at $1100^{\circ} \mathrm{C}$. The complete phase transformation from $\beta-\mathrm{CaSiO}_{3}$ to $\alpha-\mathrm{CaSiO}_{3}$ occurred at $1200^{\circ} \mathrm{C}$. The peak positions of $\beta$ - and $\alpha$-phases are in good agreement with literature [30,31]. The phase transition temperatures of combustion derived wollastonite powder were found to be lower compared to the powder obtained via other methods [30,32]. Besides, the preparation

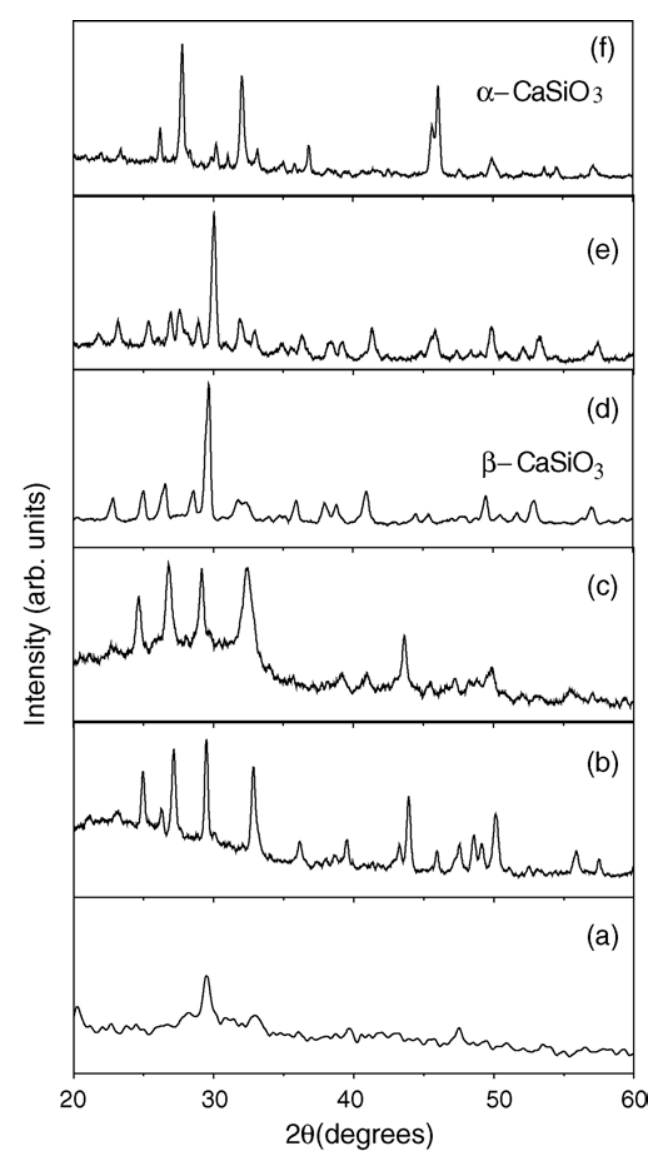

Fig. 1. Powder XRD patterns of solution combustion derived wollastonite powders (a) as formed, (b) $500^{\circ} \mathrm{C}(3 \mathrm{~h}),\left(\right.$ c) $700^{\circ} \mathrm{C}(3 \mathrm{~h})$, (d) $950{ }^{\circ} \mathrm{C}(3 \mathrm{~h})$, (e) $1100^{\circ} \mathrm{C}(3 \mathrm{~h})$ and (f) $1200^{\circ} \mathrm{C}(3 \mathrm{~h})$. 
and formation process was different from that observed for heat-treated sample of wollastonite obtained through ceramic method.

The particle size $(D)$ of wollastonite was estimated from the full width at half-maximum (FWHM) of the diffraction peak of the powders, using Sherrer's formula [33].

$$
D=\frac{k \lambda}{\text { FWHM } \cos \theta}
$$

where $\lambda$ is the wavelength of $\mathrm{X}$-ray, $\theta$ the Bragg angle, $k$ is the constant depends on the grain shape $(0.89 \AA$ for circular grains). It was observed that the average particle size of the annealed $\mathrm{CaSiO}_{3}$ samples is in the range $29-50 \mathrm{~nm}$.

\subsection{Thermal analysis}

The thermograms for solution combustion derived as formed $\mathrm{CaSiO}_{3}$ sample is shown in Fig. 2. The thermal behaviour is found to be similar to $\mathrm{CaSiO}_{3}$ gel reported by Fan et al. [34]. In the present study, the TG curve shows about $9 \%$ weight loss around $120^{\circ} \mathrm{C}$, which can be attributed to the vaporization of hydrated and coordinated water molecules. From TG curve it is also observed that further weight loss takes place at two stages, one around $530{ }^{\circ} \mathrm{C}$ with endothermic peak corresponding to $25 \%$ of total weight loss and another one at $745^{\circ} \mathrm{C}$ corresponding to total $33 \%$ weight loss. Besides to TG-DTA evidence, the IR spectra of the as formed and calcined samples at different temperatures (Fig. 4) also witnessed the presence of water molecules. This weight loss should be either the release of trapped and very strongly bonded water molecules or correspond to $-\mathrm{OH}$ groups, in agreement with the ${ }^{29} \mathrm{Si}$ MAS NMR experiments (Fig. 5) showing the transformation of $Q_{1}$ and $Q_{2}$ into $Q_{3}$. The exothermic peak at $890^{\circ} \mathrm{C}$ in the DTA curve indicates starting of crystallization of $\mathrm{CaSiO}_{3}$ and a phase transformation into $\beta$-wollastonite in confirmation with XRD results.

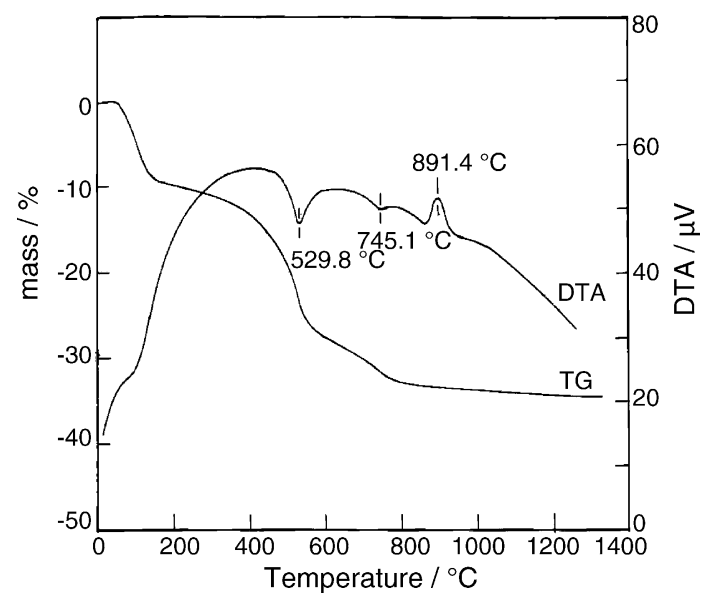

Fig. 2. The TG-DTA of solution combustion derived $\mathrm{CaSiO}_{3}$ sample.
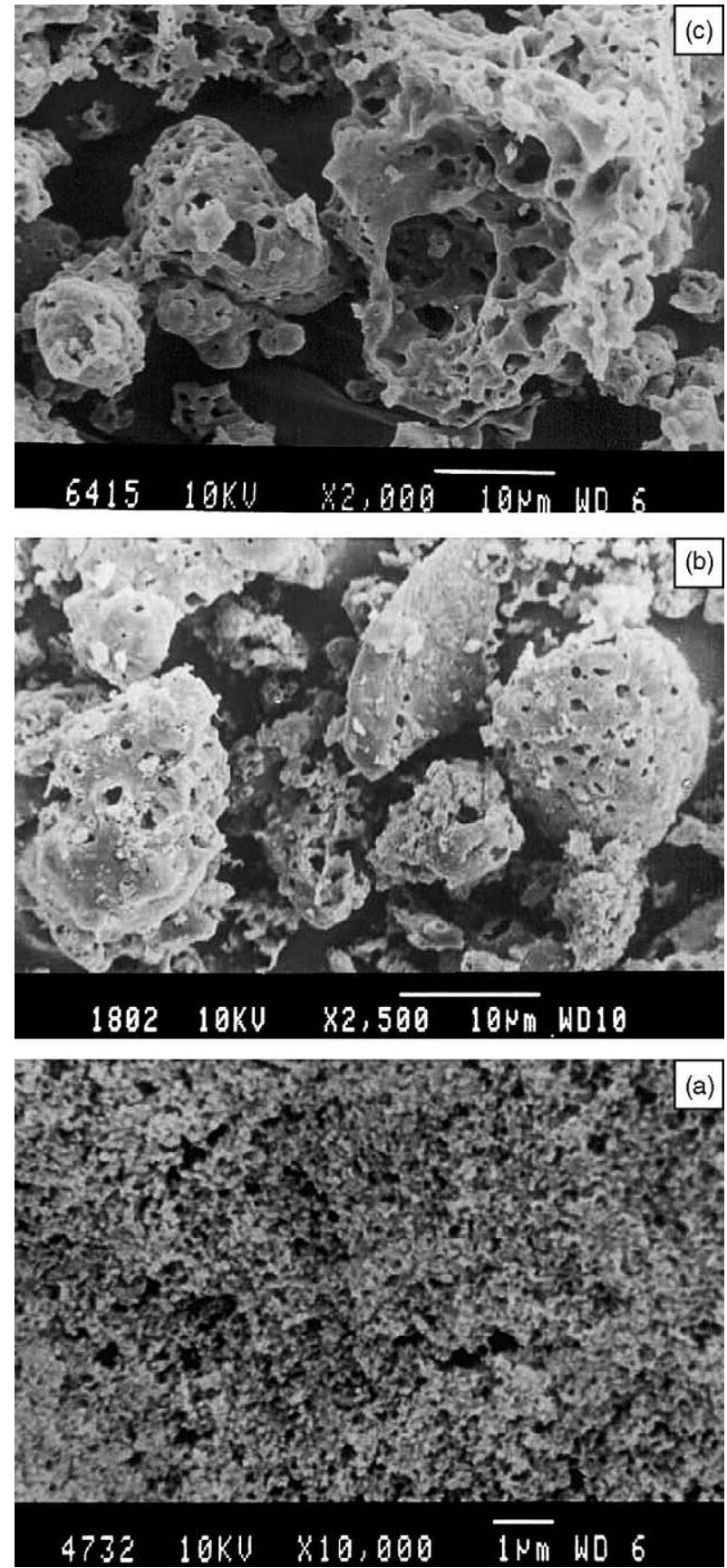

Fig. 3. The SEM images of solution combustion derived wollastonite powders (a) as formed, (b) calcined at $950^{\circ} \mathrm{C}$ for $3 \mathrm{~h}$ and (c) calcined at $1200^{\circ} \mathrm{C}$ for $3 \mathrm{~h}$.

\subsection{Scanning electron microscopy}

The SEM micrographs of the as formed and calcined wollastonite powders are shown in Fig. 3. It is interesting to note that on calcination the hallow sphere $\mathrm{CaSiO}_{3}$ powder undergoes swelling and becoming more and more porous. The pores size of the wollastonite powders is in the range $0.25-1.5 \mu \mathrm{m}$ for $950{ }^{\circ} \mathrm{C}$ and $0.5-8 \mu \mathrm{m}$ for $1200^{\circ} \mathrm{C}$. The as formed sample shows uniform distribution of nano particles, 
however, the samples calcined at 900 and $1200^{\circ} \mathrm{C}$ exhibit the particles, which are quite agglomerated.

\subsection{Porosity measurements}

The density of as prepared and sintered wollastonite was determined by the liquid displacement method. The percentage of porosity was calculated from the measured apparent density $\left(D_{\mathrm{A}}\right)$, according to the following equation [35]

Porosity $=\left(1-\frac{D_{\mathrm{A}}}{D_{\mathrm{T}}}\right) \times 100$

where $D_{\mathrm{T}}$ is theoretical density $\left(2.91 \mathrm{~g} \mathrm{~cm}^{-3}\right)$. The calculated porosity values are presented in Table 1 . It is observed that the porosity increases significantly on calcination, which can also be seen clearly from the SEM micrographs.

\subsection{Measurement of surface area}

The surface area $\left(\mathrm{m}^{2} \mathrm{~g}^{-1}\right)$ is one of the important parameters used to characterize powder samples and it is related with other parameters, such as particle size, shape and density. The surface area of the $\mathrm{CaSiO}_{3}$ samples prepared by combustion process were measured by using the Brumauer Emmete Teller (BET) equation [36] which describes the physical adsorption of a gas (nitrogen) on a solid is utilized in obtaining the surface area. The surface area of as formed wollastonite and calcined at 900 and $1200^{\circ} \mathrm{C}$ are given in Table 1 . The surface area $\left(31.93 \mathrm{~m}^{2} \mathrm{~g}^{-1}\right)$ of as formed samples is due to uniform distribution of nano sized particles as observed in SEM micrograph and the same may be supported by Sherrer's formula of XRD. On heating the sample at $950{ }^{\circ} \mathrm{C}$, the surface area decreases to $0.585 \mathrm{~m}^{2} \mathrm{~g}^{-1}$ might be due to the growth in particle size or agglomoration. On further

Table 1

Physical properties of wollastonite

\begin{tabular}{ll}
\hline Properties & Values \\
\hline Foam density $\left(\mathrm{g} \mathrm{cm}^{-3}\right)$ & 0.197 \\
Tap density $($ as formed $)\left(\mathrm{g} \mathrm{cm}^{-3}\right)$ & 0.52 \\
Powder density $\left(\mathrm{g} \mathrm{cm}^{-3}\right)$ & \\
As formed & 1.73 \\
At $950^{\circ} \mathrm{C} / 3 \mathrm{~h}$ & 0.89 \\
At $1200^{\circ} \mathrm{C} / 3 \mathrm{~h}$ & 0.77 \\
Bulk density $\left(\mathrm{g} \mathrm{cm}^{-3}\right)$ & \\
At $950^{\circ} \mathrm{C} / 3 \mathrm{~h}$ & 2.41 \\
At $1200^{\circ} \mathrm{C} / 3 \mathrm{~h}$ & 1.99 \\
Surface area $\left(\mathrm{m}^{2} \mathrm{~g}^{-1}\right)$ & \\
As formed & 31.930 \\
At $950^{\circ} \mathrm{C} / 3 \mathrm{~h}$ & 0.585 \\
At $1200^{\circ} \mathrm{C} / 3 \mathrm{~h}$ & 3.480 \\
Particles size $(\mathrm{nm})$ & \\
By Scherrer's formula & $29-50$ \\
Porosity $(\%)$ & \\
At $950^{\circ} \mathrm{C} / 3 \mathrm{~h}$ & 17.5 \\
At $1200^{\circ} \mathrm{C} / 3 \mathrm{~h}$ & 31.6 \\
\hline
\end{tabular}

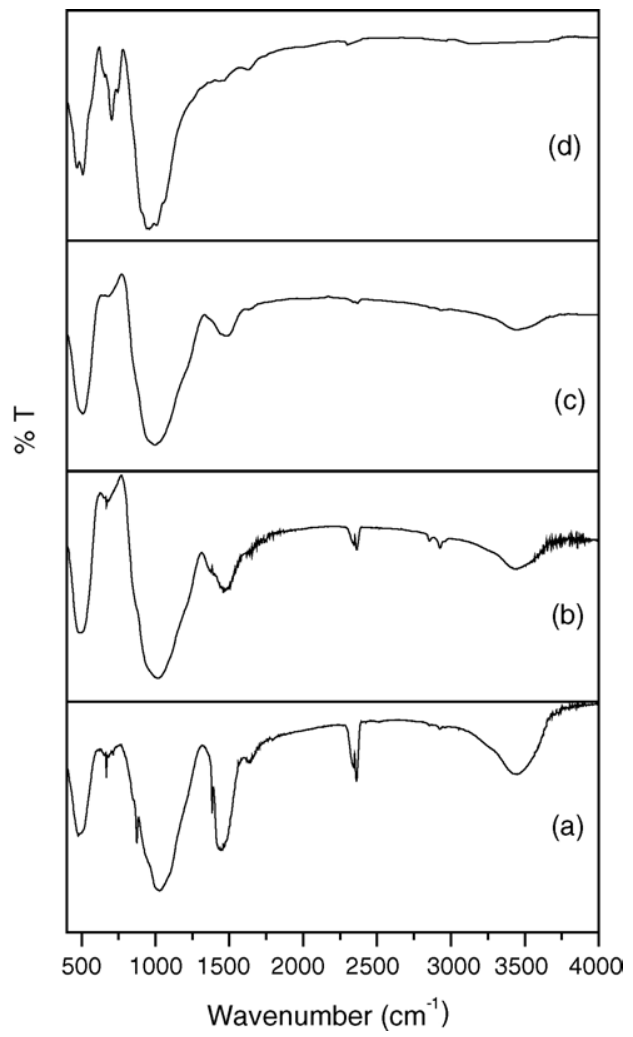

Fig. 4. FTIR spectra of the solution combustion derived wollastonite powders (a) as formed, (b) calcined at $400^{\circ} \mathrm{C}$ for $3 \mathrm{~h}$, (c) calcined at $550^{\circ} \mathrm{C}$ for $3 \mathrm{~h}$ and (d) calcined at $950{ }^{\circ} \mathrm{C} 3 \mathrm{~h}$.

calcination to $1200{ }^{\circ} \mathrm{C}$ the surface area increased to $3.48 \mathrm{~m}^{2} \mathrm{~g}^{-1}$ is due to the swelling of agglomerated powder particles.

\subsection{FTIR studies}

The Fourier transformed infrared spectra (Fig. 4) of the combustion derived wollastonite powders were recorded in order to interpret the structures of the obtained samples. Fig. 4 compares the FTIR traces of as formed $\mathrm{CaSiO}_{3}$ with those of heat-treated samples $\left(400,550\right.$ and $\left.950{ }^{\circ} \mathrm{C}\right)$. The IR spectroscopic analysis data confirms that the IR peaks at 471 , $508,680,904$ and $964 \mathrm{~cm}^{-1}$ are due to $\beta-\mathrm{CaSiO}_{3}$ [37]. The peaks in the range 1462 and $1700 \mathrm{~cm}^{-1}$ in case of as formed sample show the existence of $\mathrm{CaO}$ in the structure; however, this peak gradually decreases with calcination of the samples. The absorption bands mainly occur around $750-1170 \mathrm{~cm}^{-1}$ are due to $\mathrm{O}-\mathrm{Si}-\mathrm{O}$ vibration and absorption in the range $415-600 \mathrm{~cm}^{-1}$ is due to $\mathrm{Si}-\mathrm{O}$ vibration $[37,38]$. A decrease of the band at $3445 \mathrm{~cm}^{-1}$ with calcination temperature could be attributed to the release of water molecules trapped inside the solid matrix.

\section{7. ${ }^{29} \mathrm{Si} \mathrm{MAS} \mathrm{NMR} \mathrm{study} \mathrm{of} \mathrm{CaSiO}_{3}$}

${ }^{29}$ Si MAS NMR study has been carried out to explore different possible silicate groups that may be present in the 


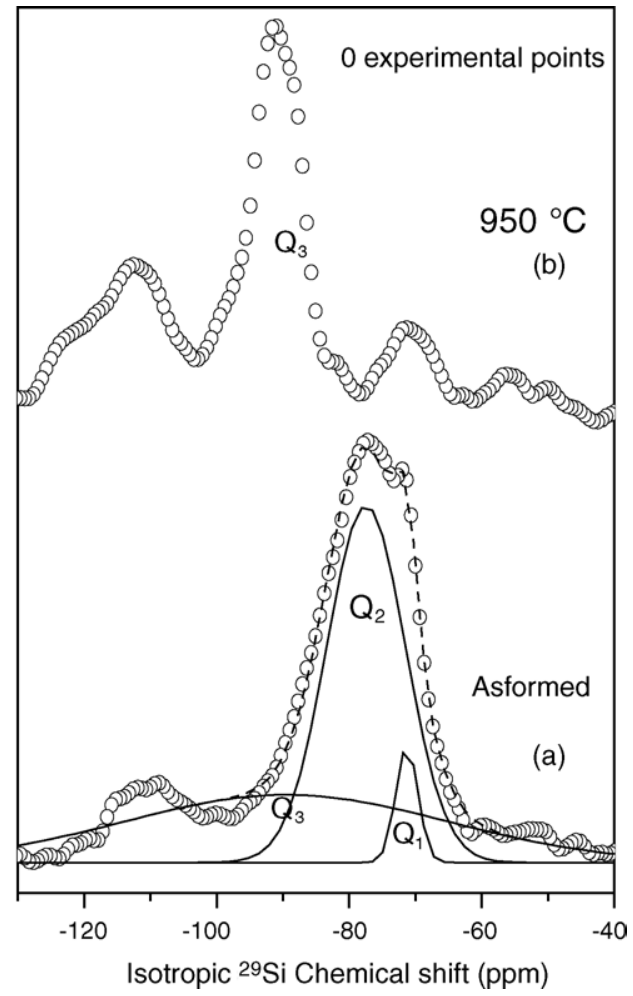

Fig. 5. ${ }^{29} \mathrm{Si}$ MAS NMR spectrum of $\mathrm{CaSiO}_{3}$ (a) as formed (deconvoluted Gaussian line shapes for each $Q_{n}$ obtained from a least-square analysis of the one-dimensional ${ }^{29} \mathrm{Si}$ MAS NMR spectrum. The observed MAS spectrum is shown in open circles and the dashed line is the theoretical fit) and (b) calcined at $950{ }^{\circ} \mathrm{C}$ for $3 \mathrm{~h}$.

sample. Since ${ }^{29} \mathrm{Si}$ is a spin $1 / 2$ nucleus, the chemical shift and dipolar effects determine the NMR line shape and the width of the spectrum only. In silicates, the basic structural unit is denoted by $Q_{n}$, where $Q$ refers to silicon in four coordination with oxygen and $n$ is the number of bridging oxygens. In general, as the alkali/alkaline earth oxides is added to vitreous silica $\left(\mathrm{SiO}_{2}\right), Q_{n}$ s with a fewer bridging oxygens are formed and the magnitude of the chemical shift becomes smaller (the silicon nucleus is less shielded). Magic angle spinning (MAS) effectively reduces the dipolar broadening and chemical shift anisotropies, thereby enabling the measurement of the isotropic chemical shift.

In crystalline materials, the technique of MAS NMR was first shown by Lippmaa et al. [39] to discriminate between different $\left(\mathrm{SiO}_{4}\right)$ tetrahedra. Fyfe et al. [40] discussed in detail the application of MAS NMR to a variety of systems. In this work, it is evident that MAS can be successfully used to remove the line broadening effects, which mask the detailed structure of the NMR resonance, and we also show that the sufficient information can be then obtained by identifying the type and quality of silicon symmetry sites in this system.

Fig. 5 shows the ${ }^{29} \mathrm{Si}$ MAS NMR spectra of as formed and calcined $\left(950^{\circ} \mathrm{C}, 3 \mathrm{~h}\right)$ wollastonite. Unfortunately, for alkali and alkaline earth silicates, ${ }^{29}$ Si MAS NMR spectra are poorly resolved, often necessary to use deconvolution technique to resolve. Gaussian peak shapes are usually assumed because they allow good fits are simple to calculate, and perhaps have some justification in terms of a random distribution of parameters. The deconvoluted Gaussian line shapes for each $Q_{n}$ are obtained from least square analysis of the onedimensional ${ }^{29} \mathrm{Si}$ MAS NMR spectra. The chemical shifts in ${ }^{29} \mathrm{Si}$ MAS NMR are generally ranges from -65 to $110 \mathrm{ppm}$ [41]. A chemical shift in the region of $-65 \mathrm{ppm}$ indicates a very weak symmetry line shape attributed to $Q_{0}$ species. Moving to more negative chemical shifts in the $-71 \mathrm{ppm}$ region, anisotropic chemical shift line shapes characteristic of positive axiality are observed and are attributed to $Q_{1}$. In the region of $-80 \mathrm{ppm}$, the anisotopic line shapes are dominated by anisoptroic chemical shift and are attributed to $Q_{2}$ species. Moving to less chemical shifts in the $-90 \mathrm{ppm}$ region, anisotropic chemical shift line shapes characteristic of negative axiality, and nearly zero asymmetry parameter are assumed and attributed to $Q_{3}$ species. In the region of $-110 \mathrm{ppm}$ a low intensity symmetry line shape attributed to $Q_{4}$ species.

In the present investigations, for the as formed sample a deconvolution of the spectra has been performed to obtain $Q_{n}$ distribution, using common assumption of Gaussian distribution of isotropic chemical shifts for each type of $Q_{n}$ unit [41-43]. After deconvoution, it displays the resonances at $-71.29,-77.45$ and $-89.52 \mathrm{ppm}$ and is assigned to $Q_{1}, Q_{2}$ and $Q_{3}$ units, respectively. Zhang et al. [41] also reported a chemical anisotropies of $-74.6 \mathrm{ppm}$ for $Q_{1},-81.7 \mathrm{ppm}$ for $Q_{2}$ and $-90.4 \mathrm{ppm}$ for $Q_{3}$. However, for fully crystalline sample of $\mathrm{CaSiO}_{3}\left(950^{\circ} \mathrm{C}\right.$ heated $\left.3 \mathrm{~h}\right)$, in the present study shows a spectrum of one fairly narrow peak centered at $-90.31 \mathrm{ppm}$ indicating a largest amount of silicon in the sample is in $Q_{3}$ groups. The centered peak is flanked by a pair or two of spinning side bands and will not be analyzed here. Similar type of observations was reported for $\mathrm{CaSiO}_{3}$ glassy sample by Murdoch et al. [44]. If we observe the as formed and calcined samples (Fig. 5a and b), the as formed sample exhibits a broad spectrum (FWHM of $16.37 \mathrm{ppm}$ ) compared to calcined sample (FWHM of $7.86 \mathrm{ppm}$ ). This may be because the as formed sample is weakly crystalline whereas the calcined sample $\left(950^{\circ} \mathrm{C}\right)$ is fully crystalline, hence the latter's spectrum is narrow.

\section{Conclusions}

Macroporous nanocrystalline wollastonite $\left(\mathrm{CaSiO}_{3}\right)$ powders have been synthesized by a novel low-temperature initiated, self-propagating and gas producing solution combustion process. The solution combustion method renders a low-temperature synthetic route to prepare fine-grained wollastonite powders with better sintering properties. It was found that single phases of $\beta-\mathrm{CaSiO}_{3}$ and $\alpha-\mathrm{CaSiO}_{3}$ were synthesized at 950 and $1200^{\circ} \mathrm{C}$, respectively. The phase transformation temperatures of combustion derived wollastonite powder were found to be lower compare to the powders obtained via solid-state reaction method. With increase in 
calcination temperature, the samples become more porous and the pore diameter increases from 0.25 to $8 \mu \mathrm{m}$. The samples calcined at $950{ }^{\circ} \mathrm{C}$ for $3 \mathrm{~h}$ has $17.5 \%$ porosity, however, the porosity increases to $31.6 \%$ on calcination at $1200{ }^{\circ} \mathrm{C}$ for $3 \mathrm{~h}$. The increase in surface areas with calcination also supports the porous nature of the powders. It was observed that the average particle size of the annealed $\mathrm{CaSiO}_{3}$ samples is in the range $29-50 \mathrm{~nm}$. The powder density of the as formed powders is $1.73 \mathrm{~g} \mathrm{~cm}^{-3}$ where as the bulk density is $2.321 \mathrm{~g} \mathrm{~cm}^{-3}$, it corresponds nearly to $80 \%$ of the theoretical density $\left(2.91 \mathrm{~g} \mathrm{~cm}^{-3}\right)$. The shape of the $Q_{n}$ distribution have been examined for the as formed $\mathrm{CaSiO}_{3}$ and calcined at $950{ }^{\circ} \mathrm{C}$ sample investigated by ${ }^{29} \mathrm{Si}$ MAS NMR exhibits the resonances at $-71.29,-77.45$ and $-89.52 \mathrm{ppm}$ and are assigned to $Q_{1}, Q_{2}$ and $Q_{3}$ units, respectively. For fully crystalline sample of $\mathrm{CaSiO}_{3}\left(950^{\circ} \mathrm{C}\right.$ heated $\left.3 \mathrm{~h}\right)$, shows only one fairly narrow peak centered at $-90.31 \mathrm{ppm}$ indicating a largest amount of silicon in the sample present as $Q_{3}$ groups.

\section{Acknowledgements}

Dr. RPSC is grateful to the Science and Engineering Research Council, SERC (Department of Science and Technology, DST) New Delhi, for the award of Fast Track research project under Young scientist programme.

\section{References}

[1] C.T. Kresge, M.E. Leonowicz, W.J. Roth, J.C. Vartuli, J.S. Beck, Nature 359 (1992) 710-712.

[2] H. Yang, N. Coombs, I. Sokolov, G.A. Ozin, Nature 381 (1996) 589-592.

[3] N.K. Raman, M.T. Anderson, C.J. Brinker, Chem. Mater. 8 (1996) $1682-1701$.

[4] D. Zhao, F. Feng, Q. Quo, N. Melosh, G.H. Fredrickson, B.F. Chmelka, G.D. Stucky, Science 279 (1999) 548-552.

[5] P. Yang, D. Zhao, D.I. Margolese, B.F. Bates, G.D. Stucky, Nature 396 (1998) 152-155.

[6] J.Y. Ying, C.P. Mehnert, M.S. Wong, Angew. Chem. Int. Ed. Eng. 38 (1999) 56-77.

[7] V.F. Stone Jr., R.J. Davis, J. Chem. Mater. 10 (1998) 1468-1474.

[8] D. Khushalani, G.A. Qzin, A. Kuperman, J. Mater. Chem. 9 (1999) 1491-1500.

[9] W. Cheng, E. Baudrin, B. Dunn, J.I. Zink, J. Mater. Chem. 11 (2001) 92-97.

[10] J.L. Blin, R. Flamant, B.L. Su, Int. J. Inorg. Mater. 3 (2001) 959-972.

[11] Y.K. Hwang, K.C. Lee, X.U. Kwon, Chem. Commun. 18 (2001) 1738-1739.

[12] H.S. Yun, K. Miyazawa, H.S. Zhou, I. Honma, M. Kuwabara, Adv. Mater. 13 (2001) 1377-1380.

[13] G.J. de A, Soler-Illia, A. Louis, C. Sanchez, Chem. Mater. 14 (2002) 750-759.
[14] G.T. Chandrappa, N. Steunou, J. Livage, Nature 416 (2002) 702.

[15] A.R. Boccaccini, M. Petitmermel, E. Wintermantel, J. Am. Ceram. Soc. 76 (1997) 75-78.

[16] G. De Schutter, L. Taerwe, Cement Concrete Res. 25 (1995) 593-604.

[17] T. Endo, S. Sugiura, M. Sakamaki, H. Takizawa, M. Shimada, J. Mater. Sci. 29 (1994) 1501-1506.

[18] G.T. Adylov, G.V. Voronov, S.A. Gornostaeva, N.A. Kulagina, E.P. Mansurova, M.Kh. Rumi, Refract. Indust. Ceram. 43 (2002) $11-12$.

[19] P.N. De Aza, F. Guitian, S. De Aza, Scr. Metall. Mater. 31 (1994) 1001-1005.

[20] P.N. De Aza, Z.B. Luklinska, M. Anseau, F. Guitian, S. De Aza, J. Microsc. 182 (1996) 24-31.

[21] P.N. De Aza, F. Guitian, S. De Aza, Biomaterials 18 (1997) 1285-1291.

[22] P.N. De Aza, F. Guitian, S. De Aza, Biomaterials 21 (2000) $1735-1741$

[23] P. Siriphannon, S. Hayashi, A. Yasumori, K. Okada, J. Mater. Res. 14 (1999) 529-536.

[24] O. Marino, P. Pernice, G. Mascola, Mater. Chem. Phys. 23 (1999) 416-421.

[25] A. Rai, N.P. Gupta, Inter. Ceram. 45 (1996) 100-103.

[26] N.I. Demidenko, L.I. Podzorova, V.S. Rozanova, V.A. Skorokhodov, V.Ya. Shevchenko, Glass Ceram. 58 (2001) 308-311.

[27] C. Ainsworth, R. Jones, J. Am. Chem. Soc. 77 (1995) 621-624.

[28] J.J. Kingsley, K.C. Patil, Mater. Lett. 6 (1988) 427-432.

[29] G.T. Chandrappa, R.G. Chandran, K.C. Patil, Int. J. Sef. Prop. High Temp. Synth. 4 (1995) 183-191.

[30] Y.H. Yun, S.D. Yun, H.R. Park, Y.K. Lee, Y.N. Youn, J. Mater. Synth. Process. 10 (2002) 205-209.

[31] K. Lin, J. Chang, Yi. Zeng, W. Qian, Mater. Lett. 58 (2004) $2109-2113$

[32] M. Kanzaki, J.F. Stebbins, X. Xue, GeoPhys. Res. Lett. 18 (1991) 463-466.

[33] H. Klug, L. Alexander, X-Ray Diffraction Procedures, John Wiley and Sons Inc., New York, 1962, p. 491.

[34] X. Fan, M. Wang, Z. Hong, G. Qian, J. Phys. Conden. Matter. 9 (1997) 3479-3487.

[35] J.M. Ting, R.Y. Lin, Y. Hsiang Ko, Am. Ceram. Soc. Bull. 70 (1991) $1167-1172$.

[36] S. Brumauer, P.H. Emmete, E. Teller, J. Am. Chem. Soc. 60 (1938) 309-319.

[37] S. Atalay, H.I. Adiguzel, F. Atalay, Mater. Sci Eng. A 304-306 (2001) 796-799.

[38] F. Branda, R. Fresa, A. Costantini, A. Buri, Biomaterials 17 (1996) $2247-2251$

[39] E. Lippmaa, M. Magi, A. Samoson, G. Engelhardt, A.R. Grimmer, J. Am. Chem. Soc. 102 (1980) 4889-4893.

[40] C.A. Fyfe, L. Bemi, H.C. Clark, J.A. Davies, G.C. Gobbi, J.S. Hartman, P.J. Hayes, R.E. Wasylishen, Inorganic Chemistry: Towards the 21st Century, ACS Symp., 1983, pp. 405-430.

[41] P. Zhang, P.J. Grandinetti, J.F. Stebbins, J. Phys. Chem. B. 101 (1997) 4004-4008.

[42] P. Zhang, C. Dunlap, P. Florian, P.J. Grandinetti, I. Farnan, J.F. Stebbins, J. Non-Cryst. Solids. 204 (1996) 294-300.

[43] J. Mahler, A. Sebald, Solid State Nucl. Mag. Res. 5 (1995) 63 78.

[44] J.B. Murdoch, J.F. Stebbinss, I.E. Carmichael, Am. Miner. 70 (1985) 332-343. 